\title{
WACANA PEMERINTAHAN DEMOKTIS DAN DINAMIKA POLITIK DI NEGERI-NEGERI TIMUR TENGAH (Saudi Arabia, Yordania, Mesir, Iran, dan Turki)
}

\author{
Muhammad Turhan Yani*
}

\begin{abstract}
A bstract: Democracy -which means an authority of the people as opposed to that of the ruler- fair general election, civil supremacy, equality before law, and government accountability are seemingly inapplicable in Arab countries. Applying democracy and sustaining it will require what Bernard Lewis calls "gradual and deliberate change", which will take these countries to a reform process from a political autocracy to an open and competitive political system. The same view is echoed by Robin Wright. To him, democracy in Arab countries will need a long time to take place. This is because culturally and socially speaking political freedom and individual participation in politics are hard to come by in these countries.
\end{abstract}

Keywords: democratic governance, political dynamism, M uslim countries.

\section{Pendahuluan}

Negara-negara di Timur Tengah pada umumnya menganut sistem politik yang belum demokratis atau tidak demokratis. Sebagian berbentuk kerajaan otoriter dan sebagian berbentuk republik tetapi juga masih otoriter. Demokrasi yang berintikan bahwa kekuasaan di tangan rakyat, pemilu yang teratur, supremasi sipil, persamaan di depan hukum, akuntabilitas pemerintahan, tampaknya masih sulit dilaksanakan di Timur Tengah. Ini disebabkan di antaranya, negaranegara tersebut masih bangga dengan hegemoni politik yang diperankannya melalui otoritas monarkhi (kerajaan).

Di samping itu, penguasa di negeri-negeri tersebut masih senang mewarisi sejarah masa Ialu dunia Islam yang para raja tersebut memiliki otoritas penuh, sebagaimana yang terjadi pada sebagian raja-raja di dunia Islam pada masa Bani U mayah dan Abbasiłah (fakta historis). Oleh karena itu, dalam kaitan ini Samuel H untington dan Fukuyama memberi komentar, bahwa Islam tidak compatable (sejalan) dengan demokrasi. Nampaknya komentar tersebut didasarkan pada realitas empirik sebagian raja-raja di dunia Islam pada masa Bani U mayah dan Abbasiłah. yang masih menunjukkan sikap otoriter.

Akan tetapi menurut penulis, komentar Huntington dan Fukuyama tersebut tidak semuanya benar karena pada dasarnya Islam memiliki titik temu dengan demokrasi pada hal-hal yang prinsipil, di antaranya adalah keadilan, persamaan, kemerdekaan, dan lain sebagainya. Apa yang dilakukan oleh sebagian penguasa dalam sejarah dunia Islam tersebut bahkan sampai sekarang tidak berarti menunjukkan representasi dari ajaran Islam itu sendiri.

\footnotetext{
* Fakultas IImu Sosial U niversitas N egeri Surabaya (UNESA).
} 


\section{Pembahasan}

Di dunia Arab, negara-negara yang rakyatnya didominasi Muslim, kalau berharap demokrasi dapat diterapkan dan berkelanjutan, maka menurut Bernard Lewis ${ }^{1}$ perlu digelar dengan cara "perubahan bertahap dan tanpa paksaan" yang berlangsung dalam "tahap-tahap lambat" melalui reformasi dari bentuk otokrasi menjadi sistem politik yang lebih terbuka dan kompetitif.

Dalam realitas panggung politik internasional di negara Islam Timur Tengah, demokrasi tampaknya dimungkinkan dalam jangka panjang. Sebab secara kultural dan historis menurut Robin Wright², inilah wilayah paling sulit di dunia bagi kebebasan politik dan demokrasi. Tetapi orang-orang Islam semakin tidak seragam dalam bersuara, dan terdapat pertumbuhan arus pluralis demokratis. Sebuah kelompok Islam reformis yang baru tumbuh sedang bergulat dengan pertanyaan tentang bagaimana melakukan modernisasi dan demokratisasi sistem politik dan ekonomi dalam sebuah konteks Islam.

Dari tahun ke tahun, dinamika politik Timur Tengah senantiasa menghadirkan kejutan yang menarik. Di antara kejutan yang terjadi adalah di Republik Islam Iran, yaitu ketika walikota Teheran Mahmoud Ahmadinejad, yang kurang dikenal luas, berhasil memenangi pemilihan presiden J uni 2005. Karena itu, dinamika politik Timur Tengah akan tetap mendominasi panggung politik internasional $2006^{3}$, dan kemungkinan juga panggung politik internasional ke depan. B erikut potret dinamika politik di lima negara di Timur Tengah

\section{Saudi Arabia}

Model dan bentuk negara-negara Arab Timur Tengah sebagian berbentuk Monarkhi (kerajaan), dan sebagian berbentuk republik. Adapun Saudi Arabia sampai sekarang masih berbentuk monarkhi absolut (meskipun ulama diajak bermusyawarah dalam masalah hukum) tanpa partai politik. Ada sebagian orang yang mengatakan bahwa keluarga besar kerajaan sama saja dengan partai itu sendiri. Pendiri dinasti kerajaan ini adalah Ibnu Saud pada abad ke-18. Ia berhasil menaklukkan semenanjung Arabia dan meraih kedudukan sebagai raja. Kerajaannya meliputi dua tempat paling suci dalam Islam, yaitu Mekkah dan Madinah.

Saudi Arabia adalah sebuah negara yang sangat religius dengan praktik Islam yang kaku. Meskipun demikian, keluarga kerajaan Saudi tetap mendapat kritikan dari kalangan fundamentalis. Sasaran kritik yang utama adalah kedekatan hubungan mereka dengan Amerika Serikat (AS), dan gaya hidup kerajaan. Keluarga kerajaan Saudi pernah dijelekjelekkan sebagai keluarga korup dan tidak islami oleh orang-orang Iran sejak revolusi tahun 1979, dan ini menimbulkan konflik dalam pelaksanaan haji orang-orang Iran di Mekkah4.

Selanjutnya, sejak masa Raja Fahd, Saudi Arabia tidak lagi menonjolkan sikap bersahabat dengan AS sepenuhnya. A palagi sejak Maret 2003, ketika Irak digempur oleh AS dan Inggris yang membentuk pasukan koalisi, negara-negara Timur Tengah yang selama tahun 1990-

\footnotetext{
${ }^{1}$ Bernard Lewis, Islam and Liberal Democrac : A H istorical Overview (J ournal of Democracy 6, no.2, 1996), 62-63. 2 Robin Wright, Islam and Liberal Democracy : Two Visions of Reformation (J ournal of Democracy 7, no.2, 1996), 64.

${ }^{3}$ Riza Sihbudi, Kejutan demi Kejutan di Timur Tengah (J awa Pos (artikel), 31 Desember, 2005), 4.

${ }^{4}$ Ian Adams, Ideologi Politik Mutakhir (Yogyakarta: Qalam, 1993), 432.
} 
2000 sering terjadi konflik yang cukup mengeras, kini mulai reda. Dan, sejak gempuran AS ke Irak, justru merekatkan kembali hubungan negara-negara Arab Timur Tengah. Suriah dan Mesir yang terang-terangan membantu AS pada serangan tahun 1991, sekarang netral. Yordania yang netral pada tahun 1991, malah sekarang cenderung membantu Irak. Saudi Arabia juga tidak lagi menonjolkan sikap membantu AS sepenuhnya. A palagi Saudi Arabia harus menghadapi tekanan internal berupa reaksi kaum militan yang menentang kedekatan Saudi dengan AS. Di mata AS pun, kredit poin Saudi agak merosot, setelah beberapa warganya diduga keras terlibat teror "11 September 2001". ${ }^{5}$

Raja Fahd memimpin Kerajaan Saudi Arabia sejak tahun 1975. Dia menggantikan Raja Khalid bin Abdul Azis. Khalid bin Abdul Azis sendiri menggantikan Faisal bin Abdul Azis (lahir 1906 dan wafat 1975) yang tewas dibunuh keponakannya, yang diduga diperalat Mossad (dinas rahasia Israel). Sejak Raja Fahd memimpin Saudi, ia sudah merencanakan keterbukaan dan reformasi Saudi Arabia. Namun di akhir kepemimpinannya ia mulai menderita sakit-sakitan, akhirnya kegiatan pemerintahan dipegang dan dijalankan oleh putra mahkota, yaitu Pangeran Abdullah. Di bawah kendali Pangeran Abdullah, Kerajaan Saudi Arabia mulai melakukan beberapa perubahan signifikan di bidang politik, antara lain; pembentukan "Majlis Syura" (DPR/MPR) tingkat lokal (propinsi/kota) melalui pemilihan umum awal J anuari 2005. Beberapa figur di luar lingkaran monarkhi, berhasil memperoleh suara. Beberapa orang di antaranya terdiri dari kaum wanita. ${ }^{6}$

Ini tentu berbeda dengan kepemimpinan sebelumnya (pra Raja Fahd), yang dalam rekrutmen politik masih bersifat eksklusif, yakni berasal dari lingkaran kerajaan. Ketika Raja Fahd memimpin, gagasan-gagasan kran demokrasi mulai dibuka lebih lebar, akan tetapi itu masih berupa gagasan yang masih direncanakan oleh Fahd yang belum diterapkan selama kepemimpinannya. Setelah kendali kepemimpinan dipegang oleh Pangeran Abdullah itulah, gagasan-gagasan Fahd mulai diterapkan.

Para pengamat Arab menyatakan, ${ }^{7}$ terobosan Pangeran A bdullah tersebut merupakan kelanjutan dari gagasan Raja Fahd yang merencanakan keterbukaan dan reformasi Saudi Arabia. Namun bentuk keterbukaan dan reformasi yang dimaksud itu masih dipertanyakan, mengingat model Monarkhi Saudi Arabia lebih ketat dari pada monarkhi-monarkhi lain di negara-negara Arab Timur Tengah. Salah satu bukti reformasi dari Raja Fahd, dimulai dari dirinya sendiri ketika ia mengubah gelar yang sudah turun-temurun digunakan oleh raja-raja Saudi Arabia Sahib al-J alałah (Paduka yang Mulia) menjadi "Khadim al-Haramayn alSharifayn" (Pelayan Dua Tanah Suci). Ia merubah gelar tersebut pada hari Rabu 29 Oktober 1986 yang bertepatan dengan $26 \mathrm{Safar} 1407 \mathrm{H}^{8}$

Ada analisis dari pengamat, bahwa program demokratisasi dan perubahan sistem pemerintahan di Timur Tengah yang digagas oleh Raja Fahd yang kemudian dilaksanakan oleh Pangeran Abdullah merupakan respon terhadap rancangan Amerika Serikat (AS). Dalam

\footnotetext{
${ }^{5}$ Fahd dan Kelangsungan Monarkhi Timur Tengah, http:// www. Pikiran Rakyat.com/cetak/2005/ 0805/02/0107.htm. ${ }^{6}$ Ibid.

${ }^{7}$ Ibid.

${ }^{8} \mathrm{Ibid}$.
} 
hal ini, memang tidak diketahui pasti, apakah memang demikian atau tidak. Sebab AS sendiri tidak berani intervensi langsung Monarkhi Saudi Arabia yang merupakan tabungan gemuk bagi negara Adidaya itu. Sebab 60\% kebutuhan minyak AS berasal dari negara-negara Arab Timur Tengah, dan setengah dari jumlah itu bersumber dari Saudi Arabia. J ika AS berani merombak Monarkhi Saudi Arabia, tidak dapat diprediksi bagaimana akibatnya. Apakah Saudi Arabia akan tunduk patuh begitu saja, atau justru melakukan perlawanan keras yang akan menjadi bumerang, karena akan menjadi momentum perlawanan seluruh negara Arab Timur Tengah yang selama ini muak tapi tidak berkutik oleh dominasi AS. ${ }^{9}$

Raja Fahd (almarhum) telah merintis jalan ke arah perubahan yang mungkin membawa pencerahan bagi negara-negara (monarkhi) Arab Timur Tengah. Atau sebaliknya mungkin membawa bencana lebih besar, mengingat AS dan kroni-kroninya tidak mau kehilangan tempat bercokol dalam menikmati kekayaan bumi Timur Tengah ${ }^{10}$

2. Yordania

Negara-negara Timur Tengah pada umumnya menganut sistem politik yang belum demokratis atau tidak demokratis, berbentuk kerajaan otoriter (yang peran dan partisipasi rakyat sangat kecil di dalamnya), republik tetapi otoriter, dan sebagainya. Praktek demokrasi belum menjadi agenda utama dalam sistem perpolitikan di Yordania. Sebagai contoh, dalam rekrutmen politik, seperti pemilihan Perdana Menteri (PM), otoritas raja masih sangat kuat, demikian pula dalam pemilihan anggota parlemen, sebagian melalui pemilihan dan sebagian melalui penunjukan oleh raja ${ }^{11}$. Namun demikian, menurut Lewis otokrasi di Yordania sedang mengalami modernisasi yang sedang bergerak ke arah kebebasan yang lebih besar ${ }^{12}$.

Merespon proses perpolitikan di Timur Tengah yang belum demokratis seperti itu, termasuk di Yordania maka Amerika Serikat (AS) memprogramkan proses demokratisasi di negara-negara Timur Tengah. Oleh karena itu, pada Konferensi Tingkat Tinggi (KTT) G-8 di Georgia, Amerika Serikat (AS), di samping membicarakan masalah ekonomi global, juga membicarakan tentang prakarsa dan upaya AS dalam melakukan demokratisasi di Timur Tengah. Negara-negara yang menjadi sasaran empuk atau obyek prakarsa George Bush tersebut pada umumnya bersikap skeptis. Mereka tidak menerima demokratisasi yang didikte oleh pihak luar, khususnya AS yang dicurigai mempunyai niat untuk menguasai kekayaan minyak Timur Tengah. ${ }^{13}$

Dalam hal ini, Raja Yordania Abdullah II menilai bahwa reformasi yang digerakkan oleh pihak luar akan mengalami kegagalan. Reformasi yang demikian tidak akan menyelesaikan masalah Timur Tengah. Raja Abdullah II mengatakan, "Proses reformasi apa saja harus datang dari dalam. Pelaku reformasi adalah vital demi keberhasilannya, dan inisiatif yang datangnya dari luar hanya akan melukai upaya para reformis sejati di kawasan kami". ${ }^{14}$

\footnotetext{
${ }^{9}$ Ibid.

${ }^{10} \mathrm{lbid}$.

${ }^{11}$ Ali Haidar, Kuliah Institusi Politik Program Doktor IAIN Sunan Ampel Surabaya, 2005.

${ }^{12}$ Lewis, Islam and Liberal Democrac : A H istorical Overview, 62-63.

${ }^{13}$ Abdul Choliq, Wijaya. Di Balik Demokratisasi Timur Tengah, http:// www. Pikiran Rakyat.com/ cetak/2004/0604/ 140804.htm.

$14 \mathrm{Ibid}$.
} 
Gagasan dan prakarsa Bush tentang demokratisasi dan reformasi di Kawasan Timur Tengah atau negara-negara Arab tampaknya lebih merupakan upaya AS untuk menggiring negara-negara Arab yang kaya minyak agar lebih bergantung pada AS. Demi menjaga dan memelihara kepentingan nasionalnya, yaitu mengamankan pasokan minyak dari Timur Tengah yang sangat dibutuhkan untuk kelangsungan industri, AS mengeluarkan "kartu truf" lain, yaitu senjata demokrasi dan reformasi. ${ }^{15}$

Gagasan demokratisasi dan reformasi Bush atas Timur Tengah mengisyaratkan adanya arogansi atau kesombongan Bush untuk memaksakan nilai-nilai Barat atas kawasan yang paling bergejolak di muka bumi ini. Kawasan itu sejak lama memang memerlukan demokratisasi dan reformasi. Akan tetapi menurut Raja Abdullah II, bagaimanapun demokratisasi atau reformasi tidak akan berjalan jika inti penyelesaian konflik negara-negara Arab dan Israel, yang menyangkut masalah hak bagi bangsa Palestina untuk mendirikan negara merdeka tidak segera diwujudkan. ${ }^{16}$

Tampaknya Bush melalui gagasan demokratisasi dan reformasi yang didengungkan ingin mengedepankan cara yang lebih lunak. G edung Puth bersumbar akan mengembangkan nilai-nilai demokrasi, penghargaan terhadap HAM, reformasi ekonomi, dan politik atas negaranegara Timur Tengah, walaupun pada kenyataannya merupakan cara dan bentuk lain dari intervensi atas negara-negara lain untuk memelihara hegemoni AS atas dunia. ${ }^{17}$

3. Mesir

Awal masuknya fundamentalisme Islam ke dalam aktivitas politik dimulai dari terbentuknya Ikhwanul Muslimin di Mesir tahun 1928. Mesir pada saat itu berada di bawah kontrol kuat Inggris. Mesir adalah negara yang paling ter-Barat-kan, walaupun sebagian penduduknya sangat mengecam dominasi Barat. Kondisi ini merupakan ekspresi dari kelompok-kelompok di dalam negara tersebut: kaum nasionalis yang memodernisasi diri dan kaum tradisionalis. Kelompok yang terakhir inilah yang mendirikan gerakan pemuda Ikhwanul Muslimin. Pada tahun 1930-an, ia menjadi calon penuh partai politik fundamentalisme pertama. ${ }^{18}$

Pendiri Ikhwanul Muslimin adalah $\mathrm{H}$ asan al-Banna. Ia selalu mengatakan bahwa dunia Islam telah dirusak oleh ide-ide Barat, karena itu perlu dilakukan pemurnian. Pada masa awal didirikan, Ikhwanul Muslimin memusatkan tujuannya untuk membangkitkan kesadaran beragama bangsa Mesir, membangun kehidupan sosial yang sesuai dengan ajaran Islam, pendidikan serta amal perbuatan. Pada fase berikutnya, Ikhwanul Muslimin berubah menjadi gerakan perjuangan untuk mencapai kemerdekaan Mesir, perlawanan terhadap penetrasi Eropa, serta upaya penegakan shariłat dan Khilafah Islamiłah di seluruh dunia Muslim. Dengan adanya perubahan orientasi ini, Ikhwanul Muslimin menjadi gerakan politik yang berusaha meraih kepentingan-kepentingan politik. ${ }^{19}$

${ }^{15} \mathrm{lbid}$.

${ }^{16} \mathrm{Ibid}$.

${ }^{17} \mathrm{lbid}$.

${ }^{18}$ Adams, Ideologi Politik Mutakhir, 433-434.

${ }^{19} \mathrm{~J} \mathrm{ohn} \mathrm{L.} \mathrm{Esposito,} \mathrm{Islam} \mathrm{dan} \mathrm{Politik} \mathrm{(J} \mathrm{akarta:} \mathrm{Bulan} \mathrm{Bintang,} \mathrm{1990),} \mathrm{184-185.}$ 
Pada awalnya, Ikhwanul Muslimin bekerjasama dengan pemerintahan nasionalis Nasser, tetapi akhirnya tidak lagi, sehingga mereka bersikap oposisi. Nasser kemudian membasmi organisasi ini secara kejam. Pentolan-pentolan Ikhwanul Muslimin yang dibuang oleh Nasser akhirnya menyebarkan ide-ide Islamnya ke seluruh dunia Arab. Dan, kekalahan Mesir dari Israel dalam perang enam hari tahun 1967 telah memaksa Nasser untuk kompromi. ${ }^{20}$

Pasca Nasser, Mesir dipimpin oleh Anwar Sadat yang mempunyai hubungan dekat dengan kalangan fundamentalis, namun ketika Sadat memutuskan untuk bersekutu dengan AS, kalangan fundamentalis menjadi gusar. Akhirnya mereka melakukan kerusuhan dan pesta pora penghancuran di distrik night club di Kairo pada tahun 1977. Kemarahan mereka semakin bertambah karena sikap Sadat yang mau menandatangani perjanjian damai dengan Israel tahun 1979. Akhirnya kaum fundamentalis merebak di mana-mana yang salah satunya membunuh Presiden Sadat pada tahun 1981. Pengganti Sadat adalah H usni Mubarak, mau tidak mau ia harus menapaki jalan sulit untuk mencegah berkobarnya fundamentalisme dengan cara memberikan sejumlah kelonggaran pada sentimen agama, walaupun akhirnya ia berubah sikap. ${ }^{21}$

Pada Pemilu tahun 1984 dan 1987, terjadi suatu pertarungan ganas dalam gelanggang politik Mesir. Arti penting itu tidak hanya terletak pada campur tangan aparat negara untuk mempengaruhi arah pemberian suara untuk kemenangan partai pemerintah (Partai Nasional Demokratik/ Partai Demokrasi Nasional (NDP) dan calon-calonnya belaka), akan tetapi juga dalam berubahnya masalah hukum Islam menjadi masalah sentral dalam perjuangan politik untuk memenangkan pemilu. Program Partai Nasional Demokratik memuat beberapa prinsip dan nilai-nilai, yang paling menonjol di antaranya adalah :"keyakinan terhadap nilai-nilai agama dan spiritual dan atas dasar itu partai memandang hukum Islam sebagai sumber pokok perundang-undangan". Akan tetapi prinsip itu dinilai sebagai manuver politik dari pada kebulatan tekad untuk menerapkan teks tersebut dalam hubungan-hubungan hukum dan struktur perundang-undangan. ${ }^{22}$

Masalah hukum Islam menjadi obyek pertarungan paling menonjol dalam pemilu Mesir tahun 1984 antara Partai Nasional Demokratik dan partai-partai oposisi bersama koalisi Wafd dan Ikhwanul Muslimin. Dalam kampanye pemilu dinyatakan bahwa hukum Islam adalah sumber pokok perundang-undangan. Akan tetapi teks semacam ini agak berubah dalam penerapan pada tataran politik praktis. Partai Wafd yang populer dengan tradisi historisnya yang berpusat pada keyakinan terhadap nilai-nilai liberalisme, konstitusionalisme, dan sekularisme, pada waktu yang bersamaan pimpinan partai ini mempunyai tingkat pragmatisme dan manuver politik yang tinggi. Di akhir bagian khusus mengenai kebebasan disebutkan sikap partai ini, yakni pemberlakuan hukum Islam, yang berbunyi: Partai berpendapat bahwa hukum Islam adalah suatu sumber orisinil perundang-undangan di negeri ini. Tetapi dalam prakteknya partai ini tidak komitmen atas sikap yang telah dikemukakan. ${ }^{23}$

\footnotetext{
${ }^{20}$ Adams, Ideologi Politik Mutakhir, 433-434.

${ }^{21} \mathrm{lbid}$.

${ }^{22}$ J ohannes den H eijer dkk. Islam, Negara dan H ukum (J akarta: INIS, 1993), 16.

${ }^{23} \mathrm{Ibid}$., 17.
} 
Demikian juga yang sering dikemukakan oleh Partai Aksi Sosialis, juga hampir sama, dan itu lebih sebagai manuver politik belaka. Sedangkan Partai Liberal Sosialis termasuk partai yang termarjinalkan, dan partai ini tidak mewakili kekuatan sosial yang berarti dan tidak mempunyai wujud dalam proses pembuatan keputusan politik ${ }^{24} \mathrm{H}$ asil yang paling menonjol dari pemilu 1984 ini adalah masuknya unsur-unsur dari gerakan Ikhwanul Muslimin ke dalam parlemen melalui partai Wafd dan tidak berhasilnya partai-partai lain meraih kursi parlemen. ${ }^{25}$ Pada pemilu 1987, peta koalisi berubah, yang semula Ikhwanul Muslimin berkoalisi dengan partai Wafd, pada pemilu 1987, ia berkoalisi dengan Partai Aksi Sosialis dan Partai Liberal Sosialis (koalisi segi tiga). Koalisi segi tiga ini mengkhususkan program penerapan hukum Islam. ${ }^{26}$

Babak Baru : Untuk pertama kali, 7 September 2005 Mesir mempunyai gawe nasional, yakni menyelenggarakan pemilihan presiden multi-kandidat yang akhirnya dimenangkan oleh H usni Mubarak dari Partai Demokrasi Nasional (NDP). Mubarak menang telak atas lawanlawannya dengan mengumpulkan 88,6\% suara. Sementara saingan terdekatnya, Ayman Nour dari Partai al-G had hanya mendapatkan 7,6\% suara, dan urutan ketiga ditempati Noaman Gomaa dari Partai Wafd dengan mengumpulkan 2,9\% suara. ${ }^{27}$

Namun pemilu kali ini kurang legitimate dan kehilangan kredibilitasnya karena partisipasi rakyat sangat rendah. Dari 31.826.248 yang terdaftar sebagai pemilih, yang berpartisipasi hanya 7.305 .063 orang, atau hanya 23\% yang mengikuti pemilu presiden. Mubarak hanya memperoleh kurang dari 10\% suara dari jumlah total penduduk Mesir 77 juta jiwa. Ini bisa dikatakan sebagai aksi boikot atas pemilu berhasil. Dalam pemilu kali ini ada ketidakpercayaan rakyat Mesir kepada Mubarak dan rezimnya. Alasan lain mengapa pemilu kali ini kehilangan kredibilitasnya karena muncul tuduhan, pemerintah melakukan kecurangan pemilu dan tidak diizinkannya lembaga swasta nasional maupun internasional ikut mengawasi jalannya pemilu. ${ }^{28}$

Selanjutnya, mengapa pemilu tetap dilangsungkan meski sejak awal sudah diketahui bahwa gawe nasional ini hanya akan merugikan penguasa sendiri? J awabnya : Pertama, rezim Husni Mubarak yang telah berkuasa sejak 1981 mendapat tekanan berat dari pemerintahan Presiden Bush untuk segera melakukan reformasi demokratis. Sebagai pemimpin negara Arab di bidang politik dan budaya, Mesir diharapkan menjadi pioner atau motor penggerak gerbong reformasi Dunia Arab. Setelah perang Irak selesai Mei 2003, Menteri Luar Negeri Amerika AS Colin Powell dan Condoleezza Rice tak henti-hentinya menekan negara-negara Arab, terutama Mesir dan Saudi Arabia, untuk segera melakukan reformasi politik guna memenangi hati bangsa Arab setelah mereka dikecewakan invasi AS atas Irak secara illegal. ${ }^{29}$ Kedua, rezim Mubarak mungkin masih percaya pada budaya politik Mesir yang selalu menghendaki pemerintah pusat yang kuat walaupun tidak demokratis mampu

24 Ibid., 19.

$25 \mathrm{lbid}$.

26 lbid., 22.

${ }^{27}$ Smith Alhadar, Kesulitan Setelah Pemilu Mesir (Artikel) (J akarta : Kompas September 2005).

${ }_{28}^{28} \mathrm{Ibid}$.

$29 \mathrm{lbid}$. 
menjamin keamanan rakyat. Perlu diketahui bahwa sekitar 70\% rakyat Mesir tinggal di sepanjang Sungai Nil, dan mereka amat bergantung pada sungai itu. Hanya pemerintahan yang kuatlah yang bisa menjamin kontinuitas aliran Sungai Nil. Dengan budaya politik seperti itu, rezim Mubarak tampaknya yakin, rakyat tidak akan memilih sistem demokrasi yang potensial menimbulkan anarki dan instabilitas politik. ${ }^{30}$

Rezim Mubarak masih jauh dari sistem demokrasi, sebagai contoh Ikhwanul Muslimin yang merupakan kelompok politik yang sangat berpengaruh, tidak bisa membentuk sebuah partai. Dalam sejarah politik di Mesir, memang Ikhwanul Muslimin pernah dinyatakan oleh pemerintah sebagai organisasi terlarang, dan pada saat itu para elit organisasi tersebut banyak yang ditahan, termasuk Hasan al-Banna, bahkan ia dibunuh oleh agen dinas rahasia pemerintah Mesir pada tanggal 12 Februari 1949. ${ }^{31}$ Demikian pula dalam hal ekonomi, rezim Mubarak yang tidak demokratis dipandang sebagai pemerintahan yang korup, yang juga berakibat pada kemiskinan rakyat. Rakyat Mesir yang hidup di bawah gariskemiskinan hingga kini sebanyak $16,7 \% .^{32}$

Rekrutmen politik yang tidak fair dalam pemilu presiden ini berdampak pada hasil pemilu yang tidak legitimate, yang juga akan menumbuh-suburkan gerakan oposisi yang semakin kuat. Dampak yang lebih mengkhawatirkan lagi adalah kian berkembangnya kelompok militan dalam negeri, seperti yang pernah terjadi pada bulan J uli 2004, mereka melakukan serangan bom di kota wisata Sharm El-Sheikh, yang dapat berdampak adanya ketidakpercayaan investor asing untuk menanamkan modal di Mesir. $\mathrm{H}$ al ini disebabkan adanya instabilitas politik dalam negeri yang masih kacau. ${ }^{33}$

\section{Iran}

Model dan bentuk negara Iran adalah Republik. Tetapi di sisi lain, salah satu negara yang paling sering dilempari tuduhan anti-demokratis oleh AS adalah juga Republik Islam Iran. Padahal, RII mempunyai sistem pemerintahan yang paling demokratis di kawasan Timur Tengah. Rakyat Iran memiliki kebebasan berpendapat. Sejak berdirinya RII sampai sekarang, setiap tahunnya berlangsung pemilu di Iran, baik di tingkat daerah maupun nasional. ${ }^{34} \mathrm{Pada}$ awal tahun 2003, pemilu dewan kota telah berlangsung di Iran dan pemilu anggota Parlemen Islam telah diadakan pada tahun 2004. Surat kabar Iran bebas untuk merefleksikan berbagai pendapat dan pandangan mereka. Di Iran juga bebas untuk mendirikan organisasi yang legal. Tetapi, Presiden Amerika masih tetap menganggap Iran tidak demokratis. Richard Butcher, juru bicara Kementerian Luar Negeri Amerika berkata: "Pemilu bukan kriteria atas demokratisnya sebuah negara". Padahal pemilu yang bebas dan umum di Iran sama sekali tidak bisa ditemui di negara-negara lain di Timur Tengah yang didukung oleh AS. ${ }^{35}$

\footnotetext{
$30 \mathrm{lbid}$.

${ }^{31}$ Khamami Zada, Diskursus Politik Islam (J akarta: LSIP, 2004), 81.

${ }^{32}$ Alhadar. Kesulitan Setelah Pemilu Mesir.

$33 \mathrm{lbid}$.

${ }^{34}$ Pernyataan G edung Putih M engenai Islam dan Iran, www.inb.it/world service/melayu RADIO/POLITIK/nopember 03/USA-iran.htm.

$35 \mathrm{Ibid}$.
} 
George W. Bush secara terang-terangan berkata: "Pemerintah di Timur Tengah yang berupa sistem diktator militer dan pemerintahan religius akan berakhir pada jalan buntu". Selanjutnya Bush menilai pemerintah Turki, Indonesia, dan Albania sebagai pemerintahan yang demokratik. Hakikatnya, maksud terselubung dari pernyataan Bush ini bahwa Washington menentang pemerintahan demokrasi agama Iran. Padahal, RII didirikan atas kehendak mayoritas rakyat Iran pada tahun 1979 dan dijalankan sesuai dengan UUD yang telah disahkan oleh rakyat. Selain itu sistem demokrasi agama adalah sistem yang sesuai dengan budaya dan kepercayaan rakyat Iran. Rakyat Iran mencintai Islam dan nilai-nilai sucinya. Ajaran Islam merupakan petunjuk hidup bagi mereka. Di pihak lain, bangsa Iran adalah bangsa yang mencintai kebebasan dan kemerdekaan serta menolak penguasaan Asing termasuk Amerika. ${ }^{36}$

Menlu AS, Collin Powel, mengkritik pemerintah RII dan menuduh pejabat Iran telah menggunakan Islam untuk mencapai tujuan politik mereka. Tidak diragukan lagi, Callin Powel dan pejabat Amerika yang lain, merupakan serangan propaganda terhadap Iran. Pernyataan anti Islam dan Iran dari Presiden dan Menlu AS itu, juga ditambah dengan sikap penasihat Kementerian Pertahanan Amerika, Richad Pearl, yang berusaha untuk menonjolkan ketidaksenangan rakyat Iran terhadap sistem politik Iran dan menekankan bahwa Washington harus mengulurkan bantuan dana dan fasilitas untuk mengubah rezim Iran dalam sebuah program jangka panjang. Pendapat-pendapat pejabat AS terbukti tidak benar karena rakyat Iran dalam berbagai kesempatan termasuk dalam pemilu selalu memperlihatkan dukungan secara besarbesaran terhadap sistem Islam. ${ }^{37}$

Masih dalam ingatan kita baru-baru ini, Iran juga baru mempunyai gawe nasional, yaitu pemilu presiden. Pemilihan presiden Iran dilaksanakan pada bulan J uni 2005 (babak pertama). Dari babak pertama menghasilkan dua calon, yaitu Akhbar Hashemi Rafsanjani (mantan presiden) yang pada babak pertama berada pada peringkat pertama dalam pengumpulan suara dan Mahmoud Ahmandinejad (Walikota Teheran yang konservatif) yang menduduki peringkat kedua. Kedua calon yang menang pada babak pertama tersebut mengikuti pemilihan presiden pada babak kedua. Hasil dari babak kedua tersebut akhirnya dimenangkan juga oleh Mahmoud Ahmandinejad (Walikota Teheran yang konservatif). ${ }^{38}$

Sebelumnya, banyak pengamat yang meramalkan bahwa Akhbar Hashemi Rafsanjani (mantan presiden) akan menang langsung pada satu babak saja, akan tetapi realitas politik tidak menunjukkan demikian. Rafsanjani hanya dapat mengumpulkan suara $21 \%$, diikuti Mahmoud Ahmandinejad yang mendapatkan 19,5\%. Itu adalah tamparan yang masih terasa sampai sekarang, khususnya di kalangan reformis. Setelah keberhasilan Mohammad Khatami tahun 1997 dan 2001, calon kalangan reformis, yaitu Mustofa Mouin hanya memperoleh $13 \%$ suara. la hanya sampai pada peringkat kelima dari tujuh orang calon. ${ }^{39}$

\footnotetext{
${ }^{36} \mathrm{Ibid}$.

$37 \mathrm{lbid}$.

${ }^{38}$ Pilpres di Iran Harus Lewat Babak Kedua, http:// www. mail archive.com/berita Radio Nederland 2005 @.

$39 \mathrm{lbid}$.
} 
Adapun rekrutmen politik dalam mencalonkan diri sebagai presiden Iran melalui pemilu harus terlebih dahulu disetujui yang oleh Guardian Council disebut "Dewan Pengawas". Selain itu juga juga masih ada badan atau instansi lain yang bersaing dalam mengadakan pengawasan. Karena itu kecurangan besar-besaran dalam pemilu tahun 2005 sampai sekarang tidak terbukti. ${ }^{40}$

Ahmandinejad adalah tokoh fundamentalis yang didukung oleh kubu konservatif Iran. Ketika masih menjadi Walikota Teheran, ia menutup beberapa pusat budaya, tempat kalangan muda biasanya berkumpul. Sekarang banyak pusat budaya yang sudah menjadi masjid. Busana yang lebih bebas juga dikecamnya. Tetapi Ahmandinejad menampilkan diri sebagai rakyat yang tidak korup, sementara Rafsanjani dikenal tidak begitu bersih.

\section{Turki}

Menurut Larry Diamond, Turki termasuk salah satu negara yang menyelenggarakan pemilu multi-partai yang kompetitif dan teratur, dengan penghitungan suara yang dilakukan dengan jujur dan para penguasa yang menjalankan kekuasaannya efektif. ${ }^{41} \mathrm{~A}$ kan tetapi di sisi lain, ada pertanyaan yang menggelitik: A pakah Turki tergolong tidak demokratis karena penggunaan kekerasan dalam menindas dengan kejam pemberontakan Kurdi atau karena pembatasan-pembatasan terhadap ekspresi damai identitas politik dan kultur suku Kurdi? Menurut definisi minimalis yang hanya menekankan pada aspek elektoral, Turki tergolong negara demokrasi, akan tetapi menurut konseptualisasi yang lebih ketat, Turki, Srilangka Colombia, dan Rusia tidak masuk dalam kategori demokrasi liberal. Negara-negara tersebut hanya kategori negara yang berdemokrasi elektoral ${ }^{42}$ yang di antaranya ditandai dengan tidak adanya keikut-sertaan kalangan sipil secara bebas, dan pengaruh militer masih kuat.

Menurut catatan Human Right Watch, World Report (1998) dalam Diamond, kemerosotan politik Turki paling mencolok adalah terjadinya penurunan hak-hak kebebasan. $\mathrm{Hal}$ ini disebabkan pengaruh politik militer yang pada pertengahan 1997 melakukan yang oleh seorang penulis editorial dijuluki "kudeta posmodern pertama" dimana militer secara diam-diam menurunkan sebuah pemerintahan koalisi yang dipimpin oleh Partai Islam Rifah dari kekuasaan dan terjadi pelanggaran hak-hak asasi manusia yang "menyebar-luas" dan mengerikan. Yang menggerakkan perkembangan-perkembangan ini adalah bangkitnya mobilisasi politik Islam, yang menentang pondasi-pondasi sekuler sistem politik Turki, alienasi politik yang memuncak karena kemiskinan, ketidak-adilan, korupsi dan ketidak-mampuan para politisi arus utama di negara tersebut, serta mobilisasi dan kekerasan separatisme etnis yang hebat ${ }^{43}$.

Masih menurut catatan Human Right Watch World Report (1998) dalam Diamond, pemberontakan besar di Turki melahirkan teror dan kekejaman yang brutal baik oleh pasukan

\footnotetext{
$40 \mathrm{lbid}$.

${ }^{41}$ Diamond, Developing Democracy toward Consolidation (Yogyakarta: Institute for Research and Empowerment (IRE Press), 2003), 11.

42 Ibid.

${ }^{43}$ Ibid., 39.
} 
pemberontak maupun negara, yang mengungsi kira-kira setengah juta suku Kurdi dari rumahrumah mereka di Turki Tenggara dan menewaskan sekitar 28.000 orang dalam tiga belas tahun konflik kekerasan. Pada akhir tahun 1995 diperkirakan, perang sipil di Turki selatan telah mengakibatkan lebih 19.000 orang tewas termasuk sekitar 2.000 pembunuhan terhadap orang yang dicurigai sebagai simpatisan PKK, dua juta lainnya terusir, serta lebih dari 2.000 desa hancur, sebagian besar dibakar oleh pasukan keamanan Turki ${ }^{44}$.

Meskipun ada perbaikan-perbaikan (di bawah tekanan Eropa dan internasional) yang mengurangi peristiwa kekejaman, demokrasi Turki terus dikotori oleh pelangaran-pelanggaran hak asasi manusia yang parah seperti: penghukuman para jurnalis kritis, pembunuhan tanpa proses pengadilan, pelenyapan, penghancuran desa-desa, dan penyiksaan, yang disertai ampunan bagi pasukan keamanan yang melakukannya ${ }^{45}$. Seperti beberapa negara demokrasi elektoral lain, yang sedang berjuang melawan pemberontakan brutal, demokrasi Turki merupakan suatu campuran antara lingkup bebas dan represif. Meskipun ada ruang bagi persaingan politik yang seru dan debat terbuka tentang banyak masalah, partai-partai politik yang secara eksplisit pro-Kurdi dilarang dan para politis pro-Kurdi dijadikan sasaran penuntutan ${ }^{46}$.

Dalam tahun-tahun terakhir, sejumlah intelektual, para jurnalis, dan penulis mendiskusikan masalah Kurdi, pelanggaran hak asasi manusia oleh pasukan keamanan, atau konflik bersenjata di Turki Tenggara dihadapi dengan represi, pemenjaraan dan penyiksaan, dan lain-lain. Meskipun ada reformasi kecil, pemerintah terus menolak hak-hak bahasa dan hak-hak kultural dasar minoritas Kurdi, melarang surat-surat kabar yang diterbitkan dalam bahasa Kurdi dan melarang stasiun-stasiun radio yang memuat siaran dalam bahasa Kurdi ${ }^{47}$

\section{Simpulan}

Corak demokrasi di negeri-negeri Muslim di Timur Tengah secara garis besar dapat diklasifikasikan sebagai berikut :

1. Saudi Arabia

\begin{tabular}{|l|l|}
\hline $\begin{array}{l}\text { Corak Demokrasi } \\
\text { di Saudi Arabia }\end{array}$ & \multicolumn{1}{|c|}{ Keterangan } \\
\hline Bentuk Negara & Monarkhi (kerajaan) \\
\hline Rekrutmen politik & $\begin{array}{l}\text { Melalui Pemilu yang dimulai J anuari 2005 (Pemilu pertama } \\
\text { kali), tapi tanpa partai }\end{array}$ \\
\hline Sistem kepartaian & $\begin{array}{l}\text { Tanpa partai, bahkan ada anggapan keluarga besar kerajaan } \\
\text { sama dengan partai itu sendiri }\end{array}$ \\
\hline
\end{tabular}

\footnotetext{
${ }^{44}$ Ibid., 73.

${ }^{45} \mathrm{lbid}$., 60

${ }^{46} \mathrm{Ibid}$.

${ }^{47} \mathrm{Ibid}$.
} 


\begin{tabular}{|l|l|}
\hline Legitimasi politik & $\begin{array}{l}\text { Lingkaran kerajaan, tetapi mulai Januari 2005 diadakan } \\
\text { pemilu pertama kali, dan akhirnya dibentuklah Majlis Shura } \\
\text { atau Parlemen (DPR/MPR) tingkat propinsi/kota }\end{array}$ \\
\hline Partisipasi perempuan & $\begin{array}{l}\text { Mulai ada perubahan sejak di bawah kendali Pangeran } \\
\text { Abdullah. Pemilu Januari 2005, menghasilkan beberapa figur } \\
\text { perempuan di luar kerajaan yang duduk di parlemen (Majlis } \\
\text { Shura). Sebelum itu, hak-hak politik perempuan tidak diberi } \\
\text { tempat. Atau dengan kata lain, rekrutmen politiknya masih } \\
\text { bersifat eksklusif }\end{array}$ \\
\hline Sistem hukum & $\begin{array}{l}\text { Hukum Islam sebagai hukum resmi negara. Ulama dilibatkan } \\
\text { dalam musyawarah masalah hukum }\end{array}$ \\
\hline
\end{tabular}

2. Yordania

\begin{tabular}{|l|l|}
\hline $\begin{array}{l}\text { Corak Demokrasi } \\
\text { di Saudi Arabia }\end{array}$ & \multicolumn{1}{c|}{ Keterangan } \\
\hline Bentuk negara & $\begin{array}{l}\text { Monarkhi (kerajaan), tetapi ada Perdana Menteri (PM). PM yang } \\
\text { dipilih disetujui raja, dan otoritasnya di bawah raja }\end{array}$ \\
\hline Rekrutmen politik & $\begin{array}{l}\text { Melalui pemilihan dan penunjukan oleh raja. Dengan } \\
\text { demikian ada Parlemen (DPR/MPR) yang sebagian anggotanya } \\
\text { ditunjuk oleh raja, dan sebagian melalui pemilihan }\end{array}$ \\
\hline Legitimasi politik & Otoritas raja \\
\hline $\begin{array}{l}\text { Partisipasi perempuan } \\
\text { dalam politik }\end{array}$ & $\begin{array}{l}\text { Sangat rendah. Pemilihan legislatif tahun 1993, hanya satu } \\
\text { perempuan yang memenangkan satu kursi (Tujan al-Faysal). } \\
\text { Pada pemilu tahun 1997 ia mencalonkan lagi sebagai kandidat } \\
\text { independen, tetapi ia kalah (tdak ada satupun perempuan yang } \\
\text { menang dalam pemilihan itu) }\end{array}$ \\
\hline Sistem hukum & Sekuler \\
\hline
\end{tabular}

\section{Mesir}

\begin{tabular}{|l|l|}
\hline $\begin{array}{l}\text { Corak Demokrasi } \\
\text { di Mesir }\end{array}$ & \multicolumn{1}{|c|}{ Keterangan } \\
\hline $\begin{array}{l}\text { Bentuk negara dan } \\
\text { pemerintahan }\end{array}$ & Presidensil dan sistem kabinet \\
\hline Rekrutmen politik & $\begin{array}{l}\text { Melalui pemilu presiden dan parlemen, dan yang } \\
\text { memenangkan pemilu parlemen duduk di dalamnya (DPR/ } \\
\text { MPR), termasuk beberapa perwakilan dari Ikhwanul Muslimin } \\
\text { (IM) yang selama ini dimusuhi pemerintah juga duduk di } \\
\text { parlemen karena di beberapa tempat IM memenangkan pemilu } \\
\text { September 2005, tetapi partai pemerintah (Partai Nasional } \\
\text { Demokratik) menjadi senjata penguasa sejak pemilu 1984 }\end{array}$ \\
\hline
\end{tabular}




\begin{tabular}{|l|l|}
\hline Sistem kepartaian & Multipartai \\
\hline Legitimasi politik & Partisipasi rakyat dalam pemilu \\
\hline Partisipasi perempuan & $\begin{array}{l}\text { Sangat rendah. Ini disebabkan lingkungan sosial dan ekonomi } \\
\text { di negara tersebut telah berjalan menentang hak-hak politik } \\
\text { perempuan, walaupun kewarganegaraan dan hak-hak politik } \\
\text { perempuan di Mesir dijamin dalam UUD 1956 }\end{array}$ \\
\hline Sistem hukum & $\begin{array}{l}\text { Hukum Islam sebagai hukum resmi dalam UUD 1956. Dan, } \\
\text { penerapan hukum Islam sebagai isu sentral dalam setiap pemilu, } \\
\text { tetapi dalam prakteknya, partai pemenang (NDP) tidak ada } \\
\text { komitmen untuk menerapkannya }\end{array}$ \\
\hline
\end{tabular}

Catatan : Dalam hal akuntabilitas pemerintahan era Husni Mubarak dipandang tidak demokratis karena pemerintahannya yang korup, yang juga berakibat pada kemiskinan rakyat. Rakyat Mesir yang hidup di bawah garis kemiskinan hingga kini (tahun 2005) sebanyak 16,7\%.

4. Iran

\begin{tabular}{|l|l|}
\hline $\begin{array}{l}\text { Corak Demokrasi } \\
\text { di Iran }\end{array}$ & \multicolumn{1}{|c|}{ Keterangan } \\
\hline Bentuk negara & Republik Islam Iran (RII) \\
\hline Rekrutmen politik & $\begin{array}{l}\text { Melalui pemilu tingkat daerah dan nasional (Pemilu parlemen } \\
\text { dan presiden). Anggota parlemen berasal dari partai yang } \\
\text { memenangkan dukungan suara }\end{array}$ \\
\hline Sistem kepartaian & Multi partai \\
\hline Legitimasi politik & Partisipasi rakyat dalam pemilu \\
\hline $\begin{array}{l}\text { Terdapat badan } \\
\text { penyeleksi calon } \\
\text { presiden }\end{array}$ & $\begin{array}{l}\text { Oleh Guardian Council disebut "Badan Pengawas". } \\
\text { Pencalonan sebagai presiden diseleksi terlebih dahulu oleh } \\
\text { suatu badan/instansi }\end{array}$ \\
\hline Sistem demokrasi & $\begin{array}{l}\text { Demokrasi agama (rakyat Iran mencintai Islam dan nilai-nilai } \\
\text { sucinya. Ajaran Islam merupakan petunjuk hidup bagi mereka) }\end{array}$ \\
\hline
\end{tabular}

5. Turki

\begin{tabular}{|l|l|}
\hline $\begin{array}{l}\text { Corak Demokrasi } \\
\text { di Turki }\end{array}$ & \multicolumn{1}{|c|}{ Keterangan } \\
\hline $\begin{array}{l}\text { Bentuk negara } \\
\text { dan pemerintahan }\end{array}$ & Parlementer dan sistem kabinet \\
\hline Rekrutmen politik & $\begin{array}{l}\text { Melalui pemilu tingkat daerah dan nasional. Anggota parlemen } \\
\text { berasal dari partai yang memenangkan dukungan suara }\end{array}$ \\
\hline Sistem kepartaian & Multipartai yang kompetitif dan teratur \\
\hline
\end{tabular}




\begin{tabular}{|l|l|}
\hline Legitimasi politik & Partisipasi rakyat dalam pemilu \\
\hline Sistem hukum & Sekuler \\
\hline
\end{tabular}

Catatan : Demokrasi Turki terus dikotori oleh pelangaran-pelanggaran hak asasi manusia yang parah seperti: penghukuman para jurnalis kritis, pembunuhan tanpa proses pengadilan, pelenyapan, penghancuran desa-desa, dan penyiksaan, yang disertai ampunan bagi pasukan keamanan yang melakukannya.

\section{Daftar Rujukan}

Adams, Ian. Ideologi Politik Mutakhir:Konsep, Ragam, Kritik, dan Masa Depannya. Yogyakarta: Qalam, 2004.

Alhadar, Smith. Kesulitan Setelah Pemilu M esir (Artikel). J akarta: Kompas September 2005.

Diamond, Larry. Developing Democracy toward Consolidation. Yogyakarta: Institute for Research and Empowerment (IRE Press), 2003.

Esposito, J ohn L. Islam dan Politi. J akarta: Bulan Bintang, 1990.

Fahd dan Kelangsungan Monarkhi Timur Tengah, http:// www. Pikiran Rakyat.com/cetak/2005/ 0805/02/0107.htm.

Haidar, Ali. Kuliah Institusi Politik. Surabaya: Program Doktor IAIN Sunan Ampel, 2005.

H eijer, J ohannes Den dkk. Islam, Negara, dan Hukum.J akarta : INIS, 1993.

Lewis, Bernard. Islam and Liberal Democracy: A H istorical O verview. (J ournal of Democracy 6 , no.2, 1996).

Pernyataan Gedung Putih Mengenai Islam dan Iran, www.inb.it/world service/melayu RADIO/ POLITIK/nopember 03/USA-iran.htm.

Pilpres di Iran Harus Lewat Babak Kedua, http:// www.mail archive.com/berita Radio Nederland 2005 @.

Sihbudi, Riza. Kejutan demi Kejutan di Timur Tengah. Surabaya: J awa Pos (artikel), 2005.

Wright, Robin. Islam and Liberal Democracy: Two Visions of Reformation. (J ournal of Democracy 7, no.2, 1996).

Wijaya, Abdul Choliq. Di Balik Demokratisasi Timur Tengah, http:// www. Pikiran Rakyat.com/ cetak/2004/0604/140804.htm.

Zada, Khamami. Diskursus Politik Islam. J akarta : LSIP, 2004. 